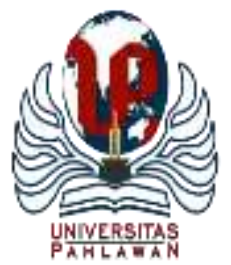

Edukatif : Jurnal Ilmu Pendidikan Volume 3 Nomor 6 Tahun 2021 Halm 4152 - 4159

EDUKATIF: JURNAL ILMU PENDIDIKAN

Research \& Learning in Education

https://edukatif.org/index.php/edukatif/index

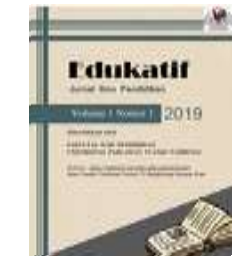

\title{
Efektivitas Penggunaan Model Mind Mapping pada Pembelajaran Daring Geografi di SMA Negeri 13 Samarinda
}

\author{
Yaskinul Anwar $^{1 凶}$, Desinarni Uban ${ }^{1}$, Zeni Hariyanto ${ }^{2}$ \\ Universitas Mulawarman, Indonesia ${ }^{1,2,3}$ \\ E-mail : yaskinul.anwar@fkip.unmul.ac.id
}

\begin{abstract}
Abstrak
Perubahan pola pembelajaran yang disebabkan oleh pandemi Covid-19 menuntut guru untuk menerapkan model-model pembelajaran yang inovatif dan konstruktif. Penelitian ini bertujuan untuk mengetahui efektivitas penggunaan mind mapping pada pembelajaran daring Geografi di SMA Negeri 13 Samarinda. Metode yang digunakan dalam penelitian ini adalah pre-eksperimen dengan rancangan one group pretestposttest design. Hasil penelitian menunjukkan bahwa: (1) keterlaksanaan pembelajaran mengalami peningkatan dengan rata-rata sebesar $73,21 \%$, (2) terdapat peningkatan aktivitas belajar siswa dengan rata-rata $76,87 \%$, (3) adanya peningkatan hasil belajar siswa dengan rata-rata pretest 55,23\% meningkat setelah diberi posttest $73,64 \%$ dengan peningkatan persentase ketuntasan siswa pada pretest $7 \%$ meningkat setelah diberikan posttest 57\%. Dengan demikian dapat disimpulkan bahwa penggunaan model mind mapping pada pembelajaran daring Geografi di SMA Negeri 13 Samarinda efektif.
\end{abstract}

Kata Kunci: Model Mind Mapping, Pembelajaran Daring, Geografi.

Abstract

Changes in learning patterns caused by the Covid-19 pandemic require teachers to apply innovative and constructive learning models. This study aims to determine the effectiveness of using mind mapping in online learning Geography at SMA Negeri 13 Samarinda. The method used in this study is a pre-experiment with a one-group pretest-posttest design. The results showed that: (1) the implementation of learning has increased by an average of $73.21 \%$, (2) there is an increase in student learning activities with an average of $76.87 \%$, (3) there is an increase in student learning outcomes with an average of $76.87 \%$. the average pretest $55.23 \%$ increased after being given the posttest $73.64 \%$ with an increase in the percentage of students' completeness at the pretest $7 \%$ increased after being given the posttest $57 \%$. Thus, it can be concluded that the use of the mind mapping model in online learning of Geography at SMA Negeri 13 Samarinda is effective.

Keywords: Mind Mapping Model, Online Learning, Geography.

Copyright (c) 2021 Yaskinul Anwar, Desinarni Uban, Zeni Hariyanto

$\square$ Corresponding author:

Email : yaskinul.anwar@ fkip.unmul.ac.id

DOI : https://doi.org/10.31004/edukatif.v3i6.1308

ISSN 2656-8063 (Media Cetak)

ISSN 2656-8071 (Media Online)

Edukatif : Jurnal Ilmu Pendidikan Vol 3 No 6 Tahun 2021 p-ISSN 2656-8063 e-ISSN 2656-8071 
4153 Efektivitas Penggunaan Model Mind Mapping pada Pembelajaran Daring Geografi di SMA Negeri 13 Samarinda - Yaskinul Anwar, Desinarni Uban, Zeni Hariyanto

DOI: https://doi.org/10.31004/edukatif.v3i6.1308

\section{PENDAHULUAN}

Geografi adalah mata pelajaran yang termasuk dalam Ilmu Pengetahuan Sosial (IPS) yang diajarkan dari tingkat sekolah dasar hingga tingkat sekolah menengah. Geografi bukanlah ilmu yang mengembangkan prinsip, konsep dan teori saja, melainkan mampu mengkaji dan menganalisis peristiwa yang terjadi di muka bumi. Berdasarkan hasil wawancara dengan guru geografi kelas XI di SMA Negeri 13 Samarinda, terdapat beberapa permasalahan yaitu pemahaman dan rasa ingin tahu mengenai ilmu geografi dikalangan siswa masih relatif rendah, siswa yang merasa mengantuk dan bosan saat mengikuti pembelajaran geografi, siswa beranggapan bahwa dalam belajar geografi hanya cukup dengan menghafal serta media pembelajaran masih bersifat konvensional seperti penggunaan ms. power point dan buku teks. Siswa yang mengalami kesulitan belajar biasanya akan merasa semakin terbebani, terlebih adanya perubahan pola pembelajaran secara daring.

Perubahan pola pembelajaran saat ini terlihat masif dilakukan disemua jenjang pendidikan akibat pandemi Covid-19 (Nistrina \& Ridwan, 2020). Situasi saat ini menjadi sebuah tantangan dalam dunia pendidikan, karena durasi penutupan yang tidak pasti, sehingga memaksa lembaga pendidikan mengubah konsep pembelajarannya dari konvensional beralih menjadi pembelajaran secara online (Ali, 2020). Dalam pembelajaran online peserta didik dituntut untuk memiliki tingkat disiplin dan motivasi yang tinggi (Winata, 2021). Apabila tidak, peserta didik akan tertinggal dan mengalami kesulitan untuk memahami materi pembelajaran.

Pembelajaran secara daring menuntut para guru untuk menguasai ilmu komputer dan teknologi informasi dan komunikasi dalam mendukung keberlangsungan kegiatan belajar mengajar (KBM) guru dan peserta didik (Basar, 2021) (Mulyana et al., 2020). Banyak platform maupun media online yang bisa diakses melalui jaringan internet oleh pengajar maupun peserta didik selama pembelajaran daring. Pada penelitian ini, peneliti menggunakan aplikasi Zoom untuk memudahkan proses pembelajaran ditengah pandemi Covid-19.

Dalam proses pembelajaran berlangsung tidak lepas dari model dan media pembelajaran. Hamalik (2013), memaparkan bahwa dalam proses belajar mengajar, lima komponen yang sangat penting adalah tujuan, materi, metode, media, dan evaluasi pembelajaran. Salah satu model pembelajaran yang dapat diterapkan guna membantu pemahaman materi oleh peserta didik adalah model pembelajaran mind mapping (peta pikiran). Olivia (2010) dan Nuryanti et al. (2014) menjelaskan kelebihan mind mapping yaitu cara mudah menggali informasi dari dalam dan dari luar otak dan cara baru untuk belajar dan berlatih dengan cepat dan ampuh.

Keberhasilan suatu pembelajaran juga tergantung dengan adanya media pembelajaran (depoedu, 2019). Media merupakan perantara yang dapat digunakan untuk menyampaikan materi dengan tepat sasaran (Nurrita, 2018). Peneliti Menggunakan Microsoft Word sebagai media siswa dalam pembuatan mind mapping. Alas an pemilihan model mind mapping yaitu dikarenakan dapat memudahkan siswa mengingat materi, memudahkan siswa dalam belajar, dan melibatkan siswa secara aktif dalam mengembangkan potensi yang dimiliki. Mengingat pembelajaran yang dilakukan secara daring, banyak siswa yang malas mencatat materi dan kurang memahami materi pelajaran yang disampaikan oleh guru.

Adapun tujuan penelitian ini untuk mengetahui efektivitas penggunaan mind mapping pada pembelajaran daring Geografi di SMA Negeri 13 Samarinda. Dengan adanya uji efektivitas penggunaan model pembelajaran diharapkan dapat menjadi alternatif pilihan media pembelajaran di SMAN 13 Samarinda yang dapat meningkatkan pemahaman materi pelajaran oleh peserta didik.

\section{METODE PENELITIAN}

Penelitian ini dilaksanakan di Sekolah Menegah Atas Negeri (SMAN) 13 Samarinda yang terletak di jalan DI Panjaitan Rt. 17, Kecamatan Sungai Pinang, Kota Samarinda, Kalimantan Timur. Penelitian 
4154 Efektivitas Penggunaan Model Mind Mapping pada Pembelajaran Daring Geografi di SMA Negeri 13 Samarinda - Yaskinul Anwar, Desinarni Uban, Zeni Hariyanto

DOI: https://doi.org/10.31004/edukatif.v3i6.1308

dilaksanakan pada Tahun Ajaran 2020/2021 disemester 1 (ganjil), waktu penelitian dilaksanakan pada tanggal 17 Oktober 2020 s/d 21 November 2020.

Metode yang digunakan dalam penelitian ini adalah metode pra-eksperimen. Rancangan penelitian digunakan pada penelitian ini adalah rancangan pretest-posttest kelompok tunggal (One Group PretestPosttest Design). Kelompok tunggal artinya pengujian dalam penelitian ini dilakukan hanya pada satu kelas. Pretest-posttest berfungsi untuk mengukur keberhasilan penelitian. Oleh karena itu, tidak ada kelompok kontrol atau kelompok pembanding yang dijadikan pengukuran.

\section{Populasi dan Sampel}

Populasi dalam penelitian ini adalah seluruh siswa kelas XI IPS SMAN 13 Samarinda tahun ajaran 2020/2021 yang terdiri dari empat kelas. Teknik sampling yang digunakan adalah random sampling, karena kelas XI IPS sifatnya homogen, tidak ad akelas unggulan maupun non unggulan yang distribusi kemampuan siswanya merata. Sampel yang digunakan dalam penelitian ini kelas XI IPS 2 dengan jumlah siswa 30 orang sebagai kelas eksperimen dengan model pembelajaran mind mapping.

\section{Teknik Pengumpulan Data}

Teknik pengumpulan data yang digunakan dalam penelitian ini menggunakan teknik tes, lembar observasi dan dokumentasi.

a. Teknik Tes

Tes yang digunakan terdiri dari pretest dan posttest yang berupa soal pilihan ganda yang berjumlah 30 soal. Pretest yaitu digunakan untuk mengukur hasil belajar siswa sebelum pemberian tindakan sedangkan posttest digunakan untuk mengetahui hasil penerapan model mind mapping pada pembelajaran daring.

b. Lembar Observasi

Lembar observasi adalah penilaian sikap terhadap perilaku atau keyakinan siswa terhadap suatu objek, fenomena atau masalah misalnya tentang kerja sama, inisiatif, mempresentasikan atau melaporkan hasil pemecahan masalah yang mereka dapatkan. Alat observasi yang digunakan berupa check list yaitu suatu daftar yang berisi poin-poin yang akan diteliti.

\section{Teknik Analisis Data}

a. Analisis Keterlaksanaan Pembelajaran Menggunakan Model Mind Mapping

Keterlaksanaan model pembelajaran diamati melalui sintaks dalam Rancangan Pelaksanaan Pembelajaran (RPP). Penelitian keterlaksanaan pembelajaran ini dilakukan dengan cara pemberian skor yang disajikan pada Tabel 1.

Tabel 1

Kriteria Skor Keterlaksanaan Pembelajaran Mind Mapping

\begin{tabular}{cc}
\hline Skor & Kriteria \\
\hline 4 & Sangat Baik \\
3 & Baik \\
2 & Cukup \\
1 & Kurang Baik \\
0 & Tidak Dilakukan \\
\hline
\end{tabular}

Berdasarkan hasil analisis data pengamatan diperoleh kriteria keterlaksanaan pembelajaran dengan kategori yang disajikan pada Tabel 2.

Tabel 2

Kriteria Interpretasi Skor Keterlaksanaan Berdasarkan Skala Likert

\begin{tabular}{cc}
\hline Skor Rerata & Kriteria \\
\hline $0-20$ & Sangat Kurang \\
$21-40$ & Kurang \\
$41-60$ & Cukup
\end{tabular}

Edukatif : Jurnal Ilmu Pendidikan Vol 3 No 6 Tahun 2021 p-ISSN 2656-8063 e-ISSN 2656-8071 
4155 Efektivitas Penggunaan Model Mind Mapping pada Pembelajaran Daring Geografi di SMA Negeri 13 Samarinda - Yaskinul Anwar, Desinarni Uban, Zeni Hariyanto

DOI: https://doi.org/10.31004/edukatif.v3i6.1308

\begin{tabular}{cc} 
61-80 & Baik \\
\hline & Sumber: Arifin, (2011)
\end{tabular}

b. Analisis Pengamatan Aktivitas Siswa

Pada lembar pengamatan aktivitas belajar siswa, terdapat 4 aspek yang diamati. Setiap aspek dinilai dengan skor berskala 1 sampai 4, sehingga skor yang diperoleh 16. Yoni (2012), memaparkan bahwa untuk menentukan persentase keaktifan pada setiap pertemuan, digunakan pada setiap pertemuan, digunakan pada setiap pertemuan, seperti pada tabel 3 .

Tabel 3

Kriteria Persentase Keaktifan Siswa

\begin{tabular}{cc}
\hline Nilai & Kriteria \\
\hline $0 \%-24,99 \%$ & Rendah \\
$25 \%-49,99 \%$ & Sedang \\
$50 \%-74,99 \%$ & Tinggi \\
$75 \%-100 \%$ & Sangat Tinggi \\
\hline
\end{tabular}

c. Analisis Deskriptif Keefektifan

Analisis yang digunakan untuk mengukur efektivitas tersebut adalah analisis deskriptif dan bertujuan untuk mengetahui efektivitas penggunaan model mind mapping pada pembelajaran daring di SMA Negeri 13 Samarinda. Dalam penelitian ini, keefektifan model mind mapping dilihat dari ranah kognitif dan psikomotorik. Kategori rata-rata hasil ranah kognitif dan psikomotorik adalah sebagai berikut:

Tabel 4

Interpretasi Nilai Efektivitas

\begin{tabular}{cc}
\hline Persentase & Kriteria \\
\hline $80 \%-100 \%$ & Sangat Efektif \\
$66 \%-79 \%$ & Efektif \\
$56 \%-65 \%$ & Cukup Efektif \\
$40 \%-55 \%$ & Kurang Efektif \\
$30 \%-39 \%$ & Gagal \\
\hline
\end{tabular}

\section{HASIL DAN PEMBAHASAN PENELITIAN}

\section{Analisis Keterlaksanaan Pembelajaran Menggunakan Model Mind Mapping}

Keterlaksanaan pembelajaran menggunakan mind mapping dilakukan melalui kegiatan observasi yang diamati oleh observer dengan menggunakan instrumen lembar pengamatan keterlaksanaan pembelajaran mind mapping. Kegiatan penelitian dilakukan sebanyak 4 kali pertemuan. Untuk mengetahui keterlaksanaan digunakan rumus persentase yaitu jumlah skor yang terlaksana dibagi dengan jumlah skor maksimal secara keseluruhan dikali $100 \%$.

\section{Tabel 5}

Data Observasi Keterlaksanaan Proses Pembelajaran

\begin{tabular}{|c|c|c|c|c|c|c|c|c|}
\hline \multirow{2}{*}{ No } & \multirow{2}{*}{ Pertemuan } & \multicolumn{7}{|c|}{ Aspek yang diamati } \\
\hline & & 1 & 2 & 3 & 4 & 5 & 6 & 7 \\
\hline 1 & 1 & 50 & 75 & 50 & 75 & 75 & 75 & 75 \\
\hline 2 & 2 & 75 & 75 & 75 & 75 & 75 & 75 & 75 \\
\hline 3 & 3 & 75 & 75 & 75 & 75 & 75 & 75 & 75 \\
\hline 4 & 4 & 75 & 75 & 75 & 75 & 75 & 75 & 75 \\
\hline \multirow{2}{*}{\multicolumn{2}{|c|}{$\begin{array}{c}\text { Persentase } \\
\text { Keterlaksanaan } \\
\text { Kategori }\end{array}$}} & $68,75 \%$ & $75 \%$ & $68,75 \%$ & $75 \%$ & $75 \%$ & $75 \%$ & $75 \%$ \\
\hline & & Baik & Baik & Baik & Baik & Baik & Baik & Baik \\
\hline & Rata-rata & & & & $3,21 \%$ & & & \\
\hline
\end{tabular}


4156 Efektivitas Penggunaan Model Mind Mapping pada Pembelajaran Daring Geografi di SMA Negeri 13 Samarinda - Yaskinul Anwar, Desinarni Uban, Zeni Hariyanto

DOI: https://doi.org/10.31004/edukatif.v3i6.1308

Keterangan:

1. Antusiasme siswa saat melakukan apersepsi

2. Siswa antusias saat proses pembelajaran

3. Guru melakukan tanya jawab materi secara garis besar

4. Guru meminta siswa untuk mengerjakan tugas pada lembar kerja siswa

5. Guru meminta siswa membuat mind mapping pada microsoft word dengan dibimbing olah guru

6. Guru mereview materi dan kegiatan pembelajaran secara garis besar

7. Siswa diberi tugas untuk membaca materi pada pertemuan selanjutnya serta mengucapkan salam penutup

Tabel 5 menjelaskan tentang hasil pengamatan keterlaksanaan pembelajaran dengan menggunakan mind mapping. Aspek yang dinilai pada pertemuan pertama sampai pertemuan terakhir mengalami peningkatan dengan rata-rata sebesar $73,21 \%$. Nilai ini termasuk dalam kategori baik, yang artinya guru telah berhasil melaksanakan proses pembelajaran menggunakan model mind mapping dengan baik. Keterlakasanaan pembelajaran merupakan salah satu acuan dalam penilaian keberhasilan pelaksanaan pembelajaran di sekolah (Bahtiar, 2013) (Pangastuti et al., 2018). Semakin tinggi keterlaksanaan pembelajaran semakin tinggi pencapaian pembelajaran di sekolah.

\section{Analisis Hasil Pengamatan Aktivitas Siswa}

Pada lembar pengamatan aktivitas belajar siswa, terdapat 4 aspek yang diamati. Setiap aspek dinilai dengan skor berskala 1 sampai 4, sehingga skor maksimal yang diperoleh 16. Hasil pengamatan aktivitas belajar siswa pada kelas XI IPS 2 dapat dilihat pada Tabel 6.

Tabel 6

Nilai Aktivitas Belajar Siswa

\begin{tabular}{|c|c|c|c|c|c|c|}
\hline \multirow{2}{*}{ Pertemuan } & \multicolumn{4}{|c|}{ Aspek yang diamati } & \multirow{2}{*}{ Jumlah } & \multirow{2}{*}{ Nilai \% } \\
\hline & A & $\mathrm{B}$ & $\mathrm{C}$ & D & & \\
\hline 1 & 1.90 & 3.80 & 2.10 & 3.66 & 11.56 & 72.29 \\
\hline 2 & 2.13 & 3.86 & 2.23 & 3.60 & 11.70 & 73.12 \\
\hline 3 & 2.26 & 3.86 & 2.20 & 3.76 & 12.06 & 75.42 \\
\hline 4 & 2.40 & 3.90 & 2.30 & 3.73 & 12.30 & 76.87 \\
\hline Rata-rata & & & & $42 \%$ & & \\
\hline
\end{tabular}

Keterangan :

$\mathrm{A}=$ Keaktifan siswa dalam bertanya atau menjawab pertanyaan.

$\mathrm{B}=$ Keaktifan siswa dalam proses pembelajaran.

$\mathrm{C}=$ Keberanian siswa dalam mengemukakan tanggapan atau pendapat.

$\mathrm{D}=$ Ketekunan siswa dalam melaksanakan tugas individu.

Hasil pengamatan aktivitas belajar siswa menunjukkan rata-rata nilai aktivitas belajar siswa dalam pembelajaran yang menerapkan model mind mapping memiliki trend peningkatan mulai dari pertemuan pertama sampai dengan pertemuan terakhir. Peningkatan ini dapat dilihat dari persentase peningkatan nilai dari $72,29 \%$ menjadi $76,87 \%$ pada pertemuan terakhir. Dengan demikian rata-rata nilai aktivitas belajar siswa pada kelas XI IPS 2 dengan menerapkan model mind mapping 74,42 dengan keaktifan siswa 74,42\%. Mengacu pada pendapat Yoni (2012) nilai 50\% - 74,99\% dari rata-rata persentase aktivitas siswa kelas XI IPS 2 termasuk dalam kriteria tinggi. Hasil ini hampir sama dengan penelitian Irawan (2020) dan Utami (2013) menunjukkan bahwa penerapan metode mind mapping dapat membuat peserta didik lebih aktif, kreatif dan termotivasi dalam mengikuti proses pembelajaran. Dalam pembelajaran mind mapping peserta didik dituntut untuk lebih aktif dan kreatif untuk membuat mapping yang semenarik mungkin (Latifah et al., 2020) (Sarmi, 2020). 
4157 Efektivitas Penggunaan Model Mind Mapping pada Pembelajaran Daring Geografi di SMA Negeri 13 Samarinda - Yaskinul Anwar, Desinarni Uban, Zeni Hariyanto

DOI: https://doi.org/10.31004/edukatif.v3i6.1308

\section{Deskripsi Hasil Pretest dan Posttest}

Data ini diperoleh melalui instrumen pretest dan posttest yang diberikan kepada siswa yang dijadikan objek penelitian yaitu siswa kelas XI IPS 2. Nilai rata-rata pretest siswa sebesar 55,23. Sedangkan rata-rata nilai posttest yaitu 72,86 . Hal tersebut menunjukkan bahwa rata-rata posttest setelah diberi perlakuan menggunakan model mind mapping lebih tinggi dibandingkan nilai pretest. Perolehan nilai siswa pada pretest dan posttest yaitu terdapat pada kriteria sangat kurang dan cukup dengan angka antara 0 sampai dengan 80 . Perolehan nilai hasil pretest dan posttest dapat dilihat pada tabel 7.

Tabel 7

Hasil Pretest dan Posttest

\begin{tabular}{|c|c|c|c|c|}
\hline \\
\hline No & Nilai & Kriteria & Pretest & Posttest \\
\hline 1 & $90 \leq-<100$ & Baik sekali & 0 & 0 \\
\hline 2 & $80 \leq-<90$ & Baik & 0 & 7 \\
\hline 3 & $70 \leq-<80$ & Cukup & 4 & 13 \\
\hline 4 & $60 \leq-<70$ & Kurang & 9 & 6 \\
\hline 5 & $0 \leq-<60$ & Sangat Kurang & 17 & 4 \\
\hline \multicolumn{3}{|c|}{ Jumlah Siswa } & 30 & 30 \\
\hline
\end{tabular}

Berdasarkan tabel 7 menunjukkan nilai pretest sebelum diberi perlakuan terdapat 4 siswa yang mendapat nilai cukup dan yang terendah terdapat 17 siswa yang mendapat nilai sangat kurang. Selanjutnya nilai posttest siswa setelah diberi perlakuan terdapat 13 siswa yang mendapat nilai cukup dan 4 siswa mendapatkan nilai sangat kurang. Dari tabel 4.3 di atas tersebut, hasil nilai pretest siswa kelas XI IPS 2 sangat rendah sedangkan nilai posttest siswa cukup memuaskan.

Hasil dari pretest tertinggi yaitu 77 dan nilai terendah 31 dengan rata-rata 55. Sedangkan nilai posttest tertinggi yaitu 86 dan nilai terendah 50 dengan rata-rata 73. Dengan demikian, hasil dari pembelajaran setelah diberikan perlakuan dengan model mind mapping terjadi peningkatan. Dengan kata lain, model mind mapping efektif digunakan pada pembelajaran daring Geografi di kelas XI IPS 2 SMA Negeri 13 Samarinda.

\section{Analisis Deskriptif Keefektifan}

Untuk mengetahui apakah pembelajaran dengan menggunakan model mind mapping efektif pada pembelajaran daring, maka dapat diketahui dengan menggunakan analisis keefektifan. Hasil analisis keefektifan dilihat dari persentase rata-rata hasil posttest siswa pada ranah kognitif dan aktivitas siswa pada ranah kognitif pada tabel 8 berikut.

\section{Tabel 8}

Perhitungan Analisa Keefektifan Model Mind Mapping

\begin{tabular}{ccccc}
\hline No & Kognitif & Psikomotorik & Rata-rata & Kriteria \\
\hline 1 & $72,86 \%$ & $74,42 \%$ & $73,64 \%$ & Efektif \\
\hline
\end{tabular}

Berdasarkan hasil perhitungan dan indikator tercapainya tujuan belajar dalam proses belajar dengan menggunakan model pembelajaran mind mapping yaitu dengan meningkatnya hasil belajar ranah kognitif $72,86 \%$ dan meningkatnya aktivitas siswa $74,42 \%$ yang merupakan hasil belajar siswa ranah psikomotorik dengan rata-rata 73,64\%. Rata-rata keefektifan tersebut termasuk dalam kritria efektif. Efektifnya penggunaan model mind maping dalam proses KBM selaras dengan hasil penelitian Karim (2018), Putri et al. (2018) dan Darmayoga et al. (2013) yang sama-sama menunjukkan bahwa penggunaan metode mind mapping cukup efektif dalam meningkatkan hasil belajar.

Model pembelajaran yang tepat haruslah memperhatikan kondisi siswa, sifat materi bahan ajar dan kondisi guru itu sendiri. Strategi belajar mengajar dalam penelitian ini tidak lepas dari peran aktif siswa secara intelektual maupun fisik dengan tujuan pengajaran yang hendak dicapai dalam ranah kognitif dan psikomotorik. Dengan demikian, efektivitas penggunaan model mind mapping pada pembelajaran daring di 
4158 Efektivitas Penggunaan Model Mind Mapping pada Pembelajaran Daring Geografi di SMA Negeri 13 Samarinda - Yaskinul Anwar, Desinarni Uban, Zeni Hariyanto

DOI: https://doi.org/10.31004/edukatif.v3i6.1308

SMA Negeri 13 Samarinda dapat membelajarkan siswa menjadi lebih efektif karena guru dapat membuat siswa lebih aktif dan kreatif dalam proses KBM pelajaran Geografi.

\section{KESIMPULAN}

Berdasarkan hasil penelitian efektivitas penggunaan model mind mapping pada mata pelajaran Geografi kelas XI di SMA Negeri 13 Samarinda, maka dapat disimpulkan bahwa penggunaan model mind mapping efektif pada pembelajaran daring di SMA Negeri 13 Samarinda. Hal ini terbukti dari adanya perbedaan hasil belajar siswa sebelum dan sesudah diterapkan model mind mapping yaitu dengan meningkatnya hasil rata-rata posttest siswa sebesar $73 \%$ serta meningkatnya rata-rata nilai aktivitas siswa setelah menerapkan model mind mapping $72 \%$ pada pertemuan pertama dan meningkat menjadi $74 \%$ pada pertemuan terakhir dengan rata-rata keefektifan 74\%. Berdasarkan analisis deskriptif nilai tersebut termasuk kriteria efektif.

\section{DAFTAR PUSTAKA}

Ali, W. (2020). Online and Remote Learning in Higher Education Institutes: A Necessity in light of COVID19 Pandemic. Higher Education Studies, 10(3), 16. https://doi.org/10.5539/hes.v10n3p16

Arifin, Z. (2011). Penelitian Pendidikan. Rosda Karya.

Bahtiar, R. S. (2013). Penggunaan Media Visual Untuk Meningkatkan Hasil Belajar Pada Tema Lingkungan Siswa Kelas Ii Sekolah Dasar. Jpgsd, 1(2), 4-15.

Basar, A. M. (2021). Problematika Pembelajaran Jarak Jauh Pada Masa Pandemi Covid-19. Edunesia : Jurnal Ilmiah Pendidikan, 2(1), 208-218. https://doi.org/10.51276/edu.v2i1.112

Darmayoga, I. W., Lasmawan, I. W., \& Marhaeni, A. A. I. N. (2013). Pengaruh Implementasi Metode Mind Mapping Terhadap Hasil Belajar Ips Ditinjau Dari Minat Siswa Kelas Iv Sd Sathya Sai Denpasar. EJournal PGSD Universitas Pendidikan Ganesha, 3.

depoedu. (2019, March 7). Peran Media Pembelajaran bagi Keberhasilan Siswa - depoedu.com. Depoedu.Com. https://www.depoedu.com/2019/03/07/edu-talk/peran-media-pembelajaran-bagi-keberhasilan-siswa/

Hamalik, O. (2013). Proses Belajar Mengajar. Bumi Aksara.

Irawan, F. (2020). Implementasi Metode Mind Mapping Dalam Pembelajaran FiQh Pada Materi Haji dan Umrah Di MTs Ma'arif NU 1 Sumbang Kabupaten Banyumas. IAIN Purwokerto.

Karim, A. (2018). Efektivitas Penggunaan Metode Mind Map Pada Pelatihan Pengembangan Penguasaan Materi Pembelajaran. IJTIMAIYA: Journal of Social Science Teaching, 1(1). https://doi.org/10.21043/ji.v1i1.3098

Latifah, Z., Ana, Hidayat, Heri, Mulyani, Heny, Fatimah, S., Ajeng, Sholihat, \& Amallia. (2020). Penerapan Metode Mind Mapping Untuk Meningkatkan Kreativitas Pada Pembelajaran Pendidikan Kewarganegaraan. Jurnal Pendidikan, 21(1), 38-50. https://doi.org/10.33830/jp.v21i1.546.2020

Mulyana, Siagian, N., Basid, A., Saimroh, Sovitriana, R., Habibah, N., Saepudin, J., Maimunah, M. A., Muaripin, \& Oktavian, C. N. (2020). Pembelajaran Jarak Jauh Era Covid-19. In Litbangdiklat Press. www.balitbangdiklat.kemenag.go.id

Nistrina, K., \& Ridwan, M. (2020). Presepsi Siswa Terhadap Pembelajaran Online di Masa Pandemic Covid19. Jurnal Sistem Informasi, 1(2), 35-40. https://ejournal.unibba.ac.id/index.php/j-sika/article/view/380/317

Nurrita, T. (2018). Pengembangan Media Pembelajaran Untuk Meningkatkan Hasil Belajar Siswa. Jurnal Misykat, 03(01), 171-187.

Nuryanti, N. W. A., Wirya, I. N., \& Asril, N. M. (2014). Penerapan Metode Mind Map Berbantuan Media Gambar Untuk Meningkatkan Perkembangan Bahasa Anak Kelompok B2. Jurnal Pendidikan Anak 
4159 Efektivitas Penggunaan Model Mind Mapping pada Pembelajaran Daring Geografi di SMA Negeri 13 Samarinda - Yaskinul Anwar, Desinarni Uban, Zeni Hariyanto

DOI: https://doi.org/10.31004/edukatif.v3i6.1308

Usia Dini Undiksha, 2(1), 1-11. https://ejournal.undiksha.ac.id/index.php/JJPAUD/article/view/3519

Olivia, F. (2010). Visual mapping : memaksimalkan otak kiri dan kanan dengan pemetaan visual. Elex Media Komputindo.

Pangastuti, R., Munfa`Ati, \& Kusnul. (2018). Penilaian Acuan Norma, Penilaian Acuan Patokan, Kriteria Ketuntasan Minimal Di Madrasah Ibtidaiah an-Nur Plus Junwangi Krian Sidorajo Jawa Timur. Jurnal Pendidikan Islam Tingkat Dasar (Al-Awlad), Vol 8(No 2), 202-217.

Putri, A. C. D., Sumardi, \& Hidayat, S. (2018). Pengaruh Model Mind Mapping terhadap Hasil Belajar Siswa pada Materi Peristiwa Sekitar Proklamasi Kemerdekaan Ilmu Pengetahuan Sosial di Sekolah Dasar. 5(1), 118-125.

Sarmi, S. (2020). Penggunaan Model Pembelajaran Mind Mapping untuk Meningkatkan Kreativitas dan Pengguasaan Materi Pelajaran Ekonomi. JKTP: Jurnal Kajian Teknologi Pendidikan, 3(1), $78-87$. https://doi.org/10.17977/um038v3i12019p078

Utami, R. H. (2013). Keefektifan Penggunaan Model Mind Mapping Materi Sumber Daya Alam Terhadap Hasil Belajar Siswa Kelas VI SD Negeri 03 Majalangu Watukumpul Pemalang. Universitas Negeri Semarang.

Winata, I. K. (2021). Konsentrasi dan Motivasi Belajar Siswa terhadap Pembelajaran Online Selama Masa Pandemi Covid-19. Jurnal Komunikasi Pendidikan, 5(1), 13. https://doi.org/10.32585/jkp.v5i1.1062

Yoni, A. (2012). Menyusun Penelitian Tindakan Kelas. Familia. 